\title{
FAN TRANSLATIONS OF SKAM: CHALLENGING ANGLO LINGUISTIC AND POPULAR CULTURAL HEGEMONY IN A TRANSNATIONAL FANDOM
}

\author{
Jennifer Duggan \\ Department of Language and Literature and Department of Teacher \\ Education, Faculty of Humanities and Faculty of Social and Educational \\ Sciences, Norwegian University of Science and Technology \\ Anne Dahl \\ Department of Language and Literature, Faculty of Humanities, \\ Norwegian University of Science and Technology
}

\begin{abstract}
The transnational success of the Norwegian multimedia series SKAM is unique in the Scandinavian context and a prime example of how fans' translation, communication, and dissemination practices can lead to a series' international success. In this study, we argue that fan translation of SKAM emphasizes the value of bi-/multilinguality by positioning Norwegian as a resource within a transnational online community, while simultaneously masking the ways in which translation into English normalizes English as the global language of communication and contributes to the Anglo-American dominance of online global media fandom. Nonetheless, fans' use of English as a lingua franca (ELF) positions it as a democratic resource, challenging native-speaker hegemony (cf. House 2013; Widdowson 1994), and fans' online translation and dissemination of non-Anglo media into English are practices which subvert the very dominance they actualize, challenging the privileged status of English by carving out space for non-Anglo linguistic expertise and positioning linguistic knowledge and the multicompetent language user as valuable (cf. Cook 1991; Cook 1992). This also creates a digital space for valuing non-Anglo popular cultural objects, languages, and cultures.
\end{abstract}

Keywords: English as a lingua franca, fandom, fan identity, multicompetence, SKAM, translation 


\section{Introduction}

While the extent of the Anglo-American role in creating and globally disseminating popular culture remains contentious, scholars agree that English-language popular culture "is a powerful global economic force" (Williams 2012:20) - as well as a powerful linguistic one (Crystal 2012). Because global popular culture has been heavily Anglo-American influenced, media fan studies predominantly focus on English-language media and English-using fans (Chin \& Morimoto 2013, Chin, Punathambekar, \& Shresthova 2018, Coppa 2006, Gray, Sandvoss, \& Harrington 2007, Harrington \& Beilby 2007, Hellekson \& Busse 2006, Jenkins \& Scott 2013). However, new media technologies have increased the flow of popular culture across borders, "bringing languages, cultures, and texts into contact as never before" (Williams 2012:18). Fans' language use and non-Anglo fandoms have thus been described as key areas of future study (e.g. Click, Gray, Mittell, \& Scott 2018).

A number of Scandinavian series have enjoyed international success in the early twenty-first century, due in large part to the increasingly diverse ways in which digital media are shared transnationally (e.g. Chin \& Morimoto 2013, Jenkins, Ford, \& Green 2013, Morimoto 2018, Williams 2012). One example is the Norwegian teen series SKAM. The series was never intended for international distribution, yet it gained a global following. Since it was never officially subtitled or otherwise made available in English or other languages, its international success was only possible due to fans' translating and sharing of the series.

Fan translation practices in this context highlight a number of concerns central to fan studies today, including questions of how social relations and power structures are enacted in a (supposedly) deterritorialized online world, tensions between the global and the local, and how cultural objects can become the focal point for transcultural expressions of identity (Chin \& Morimoto 2013, Gray, Sandvoss, \& Harrington 2007, Williams 2012). Moreover, it demonstrates how fans' use of English contradictorily results in "increased ... community diversity ... and increased linguistic and cultural nationalism" (Pennycook 2003:521). Despite this, little attention has been paid to fans' metadiscourses regarding translation and the tensions it may cause between local and transnational fans and between competing language ideologies. Additionally, while some scholars have briefly commented on the contradictions inherent in a transnational, English-language fandom centered on a non-English-language series, none have based their comments on a case study. This study aims to fill this gap.

The contradictions which we identify highlight issues of language ideology (e.g. Woolard \& Schieffelin 1994), in particular regarding three aspects of users' beliefs about language: the ideal of the native speaker; the perceived high prestige of English at the cost of other, local languages; and local (national) language protectionism. We discuss fans' meta-discussion of 
language, transnationality, and translation by presenting an analysis of the comments on the official website for season three of SKAM - a season in which the series experienced an exponential increase in international popularity. We consider how the comments relate to the concerns of fan studies as well as those of the use of English as a lingua franca (ELF).

By positioning Norwegian as a resource within a transnational online community and simultaneously masking the ways in which translation into English normalizes fans' use of ELF, fan translations contribute to the dominance of English on the Internet. However, fans' online translation and dissemination of non-Anglo media into English also subvert the very dominance they actualize by positioning the multicompetent language user as invaluable (Black 2009, Cook 1991, 1992). Fans' use of ELF challenges the privileged position of the native English speaker (House 2013, Widdowson 1994) and at the same time suggests that languages other than English are valuable resources available to only a privileged few. Many fans appear to appreciate the opportunity to share SKAM transnationally that translation into English affords, yet, as our analysis will show, some fans seem to consider translation into English to betray the Norwegian fan community, revealing differences in fans' linguistic and cultural ideologies.

\section{Background}

\subsection{SKAM}

SKAM was first released on a series-specific website by the Norwegian national broadcaster NRK in September 2015. Its format was innovative: Individual clips of a few minutes, appearing to take place in real-time and in modern-day Oslo, and the main characters' social media interaction, such as Instagram posts, were published on the website. At the end of the week, clips were gathered together and shown as one cohesive episode. ${ }^{1}$ In total, four seasons were produced, each with a different main character.

The series became a phenomenon with a large fan base, first in Norway and then internationally. During season three, international fans' requests for official translations and views from outside of Norway on the SKAM website increased rapidly. Both were a problem for the series, as copyrights for the music used had been obtained for a national audience only. For this reason, official subtitles in English were never provided, and eventually, nonScandinavian IP addresses were blocked from accessing the site.

In reaction, fans provided translations in the comments section on the official site, as well as subtitling and sharing episodes for their non-Norwegianspeaking peers elsewhere. The international fandom became large and loyal enough to ensure the victory of SKAM's season three couple, Isak and Even, as TV's Top Couple 2017 in E!Online's March 2017 poll (Bricker 2017), in competition with couples from internationally distributed American shows. Moreover, since the end of the Norwegian series in June 2017, the show has

1 For an overview of SKAM's innovations in serial narratological structure, see Andersen \& Linkis 2019. 
been remade in France (Skam France), Italy (Skam Italy), Germany (Druck), the US (Skam Austin), the Netherlands (Skam NL), Spain (Skam España), and most recently, in Belgium ( $w t F O C K$ ). The success of the original series and development of international versions highlights the role of the fan translator in this particular fandom as especially noteworthy. The series could not be officially translated due to music-license restrictions, yet translation from Norwegian was necessary for SKAM to reach a global audience, as Norwegian is not widely spoken globally. Despite the prestige that English enjoys internationally, not least in youth culture, in the sharing of the series, it can be argued that knowledge of Norwegian was a scarce and sought-after resource, while competence in English was seen as given.

\subsection{Transnational media fandoms}

The term "fandom" describes active on- and offline fan communities (Coppa 2006, Hellekson \& Busse 2006, Hills 2002a, Jenkins 1992/2013). These communities have been described as both collaborative and participatory (Jenkins 1992/2013), yet at times also "competitive, argumentative, and factional" (Hills 2002a:1). Fan cultures have therefore been theorized to be communities in which there is a tension between democratic equality and social hierarchy (e.g. Hills 2002a, Jenkins \& Carpentier 2013). In these communities, there also exists a tension between consumerism - with the fans' continued, deep focus on the object of fannish affection - and resistance to capitalistic structures - through fans' sharing of media, volunteerism, and widespread use of "gift economics" (Hills 2002a:27-45, see also Jenkins, Ford, \& Green 2013). There is therefore a constant tension between top-down corporate structures of power and bottom-cup consumer-driven pressures (Hills 2002a, Jenkins, Ford, \& Green 2013).

Because the study of media fans developed alongside the late twentiethcentury feminist turn and positioned itself against studies characterizing fans as deviant (e.g. Coppa 2006, Hellekson \& Busse 2006, Hills 2002a, Jenkins 1992/2013), fan studies scholars emphasize reflexive practice, alliance with the research subject(s), mixed-methods approaches, and foregrounding researchers' situatedness (e.g. Geertz 1973, Harding 1995, Haraway 1985/2006, Hellekson \& Busse 2006, Hills 2002a, Jenkins 1992/2013). As such, fan studies has traditionally prioritized reflexive (auto)ethnographic and cultural studies perspectives rather than quantitative, empirical scholarship. Fan studies has also, productively but at times problematically, privileged introspection and reflection, and thus the voices and experiences of academics who are themselves fans, which in the early stages of fan studies resulted in what Hills (2002a:15) calls "a rather dismaying short-sightedness."

One aspect of this "short-sightedness" particularly relevant to the present paper is the almost exclusive focus on Anglo-American experiences of fandom and English-language media, as well as on the academic-fan experience (e.g. Chin \& Morimoto 2013, Coppa 2006, Harrington \& Beilby 2007, Hellekson 
\& Busse 2006, Hills 2002b, Jenkins 1992/2013). This is because media fan studies predominantly developed as a field in in the United States and because many fan scholars are monolingual English speakers (Chin, Punathambekar, \& Shresthova 2018, Click, Gray, Mittell, \& Scott 2018). Yet online media fandom is an increasingly transcultural space in which "sustained crossborder relationships, patterns of exchange, affiliations, and social formations" (Vertovec 2009:2) are constantly developing and shifting. Not only do fans in different locations interact online but the objects circulating originate in various places and cultures (Chin \& Morimoto 2013, Morimoto 2018, Williams 2012). Media fandom has proved to be a transnational and transcultural - or even "counter-nationalist" - milieu which "exceed[s] hegemonic state definitions of the "national"' (Morimoto 2018:282).

As academics who are attempting to categorize and analyze social practices in specific fan communities, we therefore need to consider the varied ways in which different groups are interacting with global materials in their own local contexts (Chin \& Morimoto 2013, Hills 2002b, Williams 2012). In considering how a sense of individual and community identity is built within a fandom, then, we must consider not only how local, national, and global contexts inflect individuals' interaction with transnational communities but also the "different socialization agents, different cultures, different pathways to identity formation, and different conceptions of the best end goals ... in play" (Jensen 2003:195). Fan studies has always been interdisciplinary but has nonetheless maintained a focus on identity and culture (Harrington \& Beilby 2007). An important aspect of both identity and interaction in any transcultural space, which has so far been left out of mainstream fan studies, is language.

\subsection{Language use in transnational media fandoms}

Although language is acknowledged as an important aspect of fandom (Williams 2012), there remains very little focus on the nexus of linguistic repertoire and fans' sociocultural experiences outside of acknowledgements that there ought to be more focus on international fans in future scholarship (Chin, Punathambekar, \& Shresthova 2018, Click, Gray, Mittell, \& Scott 2018). Language, identity, and community are interlinked in a complex relationship; however, language has rarely been discussed in fan studies. Focus on language as a subject has predominantly been limited to translation practices. Where translation has been considered in fan studies - largely in relation to the study of Anglo-American fans of Asian cultural objects (e.g. Deppey 2005, Díaz Cintas \& Muñoz Sánchez 2006, Hills 2002b, Fabbretti 2017) - it is largely due to "academic fascination" with fan cultures which appear "to reverse the narrative of US cultural imperialism" (Hills 2002b:2). However, "fandom and national identity might have a more complex relationship, one that does not simply locate fan cultures 'in' a given national context, 'against' other national contexts, or as 'appropriating' transcultural products in a global economy/ 
culture" (Hills 2002b:2). As we will see, the question of language use in the SKAM fandom reflects this tension between the national and the international, as well as between local language protectionism and a desire for international recognition of local cultures.

Chin and Morimoto (2013:93) suggest using a "broad framework for the exploration and interrogation of border-crossing fandoms" which does not focus on national identity. We must consider the ways in which the logic of fan socialization may reflect "transculturation," or "socialization to multiple modes of belonging and participation across national boundaries" (Lam 2006:173). In doing so, we must consider not only the potential of transculturation but also the frustrations, miscomprehensions, and struggles that result from transcultural communication, which is "at times difficult, chaotic, and tense, but also possible and encouraging" (Williams 2012:2528). Of particular interest to this study are both the use of translation and the assumptions made by fan translators about their transcultural audience and that audience's linguistic competencies. However, we are also interested in the different language ideologies made apparent in fans' meta-discussions of translation from Norwegian.

For Hills (2002a), fandom is essentially contradictory and therefore difficult to theorize. To the points of contradiction which he lists (Hills 2002a), we wish to add "language use" and "pride in cultural products." The tensions of globalization can, seemingly contradictorily, lead to both an increase in both the "prevalence of English" and "linguistic and cultural nationalism" (Pennycook 2003:521, see also Williams 2012). The SKAM fandom is an excellent example of this. As we will show in our analysis, below, Norwegian fans felt pride in the show and desired to share it with the world; however, their feelings about the necessary use of English, rather than Norwegian, to achieve this sharing caused tensions amongst Norwegian fans. This tension may reflect a level of linguistic and cultural protectionism.

SKAM has already been investigated in several linguistic studies. Among these are a master's thesis (Hersdal 2018) providing a sociolinguistic study of meta discourses about Norwegian language use among Norwegian and Danish fans and a thesis on fans' linguistic choices when translating/subtitling the show and the effect of these choices on fans' perceptions of characters (Bjørkedal 2018). Quist and Skovse (2017) discuss intra-Scandinavian debates about Norwegian youth slang and non-Scandinavians' interest in learning Norwegian as a result of the series. To our knowledge, however, no study to date has addressed fans' meta discourse regarding translation, nor has one directly discussed the contradictions inherent in an international, English-language fandom centered on a non-English-language series. Thus, while these studies contribute to our knowledge about attitudes to specific linguistic choices made in the series and in translations, we provide the first discussion of fans' attitudes towards the act of translation itself. In particular, we demonstrate that the relationship between and status of the two languages 
in question - that is, English and Norwegian - is complex, contradictory, and sometimes tense.

\subsection{The roles of English}

The contradictions in the statuses of English and Norwegian in the SKAM fandom illustrate the unique role of English in global communication. While it does not have the largest native speaker population (Simons \& Fennig 2018), estimates indicate that it far outnumbers all other languages spoken globally if additional language users are counted (e.g. Crystal 2008, House 2013). Not least, as already mentioned, popular culture tends to be consumed predominantly in English in many countries. Certainly in Scandinavia, English levels are generally assumed to be high (Education First 2017), especially as regards the consumption of popular culture (e.g. Preisler 1999). Notably, new forms of media that are increasingly replacing traditional broadcast television are English-dominated: A recent survey of Norwegian children's media habits found that children as young as 3-11 watched short online videos in English slightly more often than in Norwegian (TNS Kantar 2017).

Views of this situation vary. Crystal (2012), for example, imagines a future where English may remain the international language of communication while other languages are maintained for local communication. Phillipson (2009), on the other hand, describes the spread of English as "linguistic imperialism." In Norway, conflicting sentiments can be found, with English typically described as a trendy and fashionable language of prestige (Språkrådet 1990, Johansson \& Graedler 2002), but there is also concern that Norwegian is being replaced in important domains, such as popular culture and higher education (e.g. Mæhlum 2008, Språkrådet 2017), and some metaphorically describe English as an invading force (Graedler 2014). These concerns are found not only among authorities, such as the Language Council of Norway, but also among the general population, including young people (Graedler 1998). Arguably, protectionist ideologies are particularly strong in Norway. Dialect protection and traditional resistance to both loan words and the historical influence of Danish on the Norwegian language (Graedler 1998) are strong and are considered to demonstrate both local and national belonging and pride.

Another important issue when it comes to the role of English globally, especially in high-proficiency contexts such as Scandinavia, is the ideal of the native speaker. The ideology of native language use as more authentic, and of the native speaker as the authoritative language user, is pervasive both in society and in many strands of linguistic research (Woolard \& Schieffelin 1994). In the case of English, an important debate took place in the early 1990s (e.g. Quirk 1990, Kachru 1991) over whether the (standard variety) native speaker should be the ideal for English L2 learning and whether non-native forms in L2 English are best viewed as acquisition failure or as natural variation in language use. With the spread of English as the main language of international 
communication, in which most interactions now take place between nonnative speakers (Seidlhofer 2005), traditional classifications of English use have increasingly been challenged. So-called foreign-language speakers of English may not be striving for native speaker standards in their English use but rather simply for effective communication (e.g. Hülmbauer 2009, House 2013). As such, second and foreign language users are not best viewed as deficient speakers compared to the norms of an idealized monolingual speaker but rather as "multicompetent" speakers whose knowledge of multiple languages will naturally lead to a language competence different from but in fact richer than that of monolingual speakers (Cook 1991, 1992).

\subsection{Multicompetence and transnational media fandoms}

Fan translation practices can be argued to bean example of such multicompetent language use. In translation, media, cultural, and fan studies, focus on fan translation practices is relatively new, although fans have been translating, subtitling, and sharing texts since at least the 1970s (Deppey 2005, DiazCintas \& Muñoz Sànchez 2006, Fabbretti 2017, O’Hagan 2009, O’Hagan 2011, Spolidorio 2017). The two types of fan translation most commonly studied are Japanese-English fansubbing (fan subtitling) and scanlation (the translation of manga, a type of comic) (Deppey 2005, Diaz-Cintas \& Muñoz Sànchez 2006, Fabbretti 2017, O’Hagan 2009, 2011). However, some studies have recently emerged which examine English to/from a European language translations (e.g. Massida 2015, Spolidorio 2017, Švelch 2013).

As translation is an innately communicative practice, focus within this subfield of fan studies is necessarily on communities of fans united by their shared interest in a media text rather than individual fan practices. Fan translation thus relates both to the focus on communities of practice common to applied linguistics and translation studies, as well as community-focused fan and media studies. Studies of fan translation practices have thus focused on fans' methods of translation and the communities, technologies, and knowledge required for fans to successfully translate and subtitle/dub digital media from one language to another (e.g. Diaz-Cintas \& Muñoz Sànchez 2006, Fabbretti 2017, Massidda 2015, O’Hagan 2009, 2011). Others have assessed the perceived quality of translations (Diaz-Cintas \& Muñoz Sànchez 2006, Švelch 2013). However, to our knowledge, none have focused on the role linguistic use plays in defining fans' relationships with each other as well as their transcultural identity-building practices. This study aims to fill this gap. It analyzes fans' meta-discussions of translation and language choices, how these discussions reflect fans' concerns regarding the local and national versus the transnational, the importance of language to fan experience, and fans' relationships with one another across linguistic and national boundaries.

As in many transnational communities, the language of choice in online media fandoms tends to be English. The use of English by non-native users in such communities has not been widely studied; the vast majority of fan 
scholarship focuses on English-using fans and does not distinguish between L1 and L2 users of English. Where L2 users have been studied, focus has generally been limited to the language learning opportunities available through fandom (e.g. Black 2005, 2008, 2009), that is, seeing non-native English users as learners rather than as multicompetent users, or, as in the above-mentioned studies, on fan subtitling practices, subtitle quality, or the knowledge and skills fans require to effectively translate and subtitle a series (e.g. Diaz-Cintas \& Muñoz Sànchez 2006, Fabbretti 2017, Massidda 2015, O’Hagan 2009, 2011, Spolidorio 2017, Švelch 2013).

\section{Method}

We focus on translations to English found in the comments section of the official SKAM website for several reasons. First, we do not wish to draw attention to fans whose work is not tacitly authorized by the series' producers. As the comments section on the official website was moderated by the show's producers, we can assume that fan-provided translations in this forum are not seen as breaches of fair use or intellectual property law, while fans who posted translations (and perhaps copies of media) on other forums run the risk of legal reprisal. Secondly, the Norwegian Centre for Research Data (NSD) requires commentator anonymity. The commentators on the SKAM site appeared not to use known pseudonyms for themselves, such as screen names they might regularly use on social media, as users were required to enter a pseudonym every time they commented. Some used first names or initials, while others identified themselves by nationality, nickname, or in other ways that did not allow their identification. Only comments with no explicit identifying information are quoted.

This study examines the comments posted for season three. This was the season in which SKAM gained an international fandom but before the site was geo-blocked. We searched the comments sections on the official web page using the search terms "transl*" and "Engl*" in order to identify comments providing or asking for translations. Comments simply stating, "I watch the show using google translate," or excusing themselves for writing in English were excluded from the data set.

This study has a qualitative focus. Through thematic analysis, initial themes were first identified inductively in the data. We then further refined these themes into broad codes. Data were coded using these codes and analyzed.

Approximate numbers have been provided as a rough guide to proportion. Around 1,200 individual entries were identified, including translations with no meta-comments and translations and other posts containing meta-discussion of the translations. However, it is not possible to give exact numbers as the meanings of some comments are unclear and some comments contained multiple themes. Sometimes, seemingly identical comments are posted at different times, making it difficult to determine whether they should be 
identified as separate comments or as re-postings. Finally, the comments were modified by NRK, so our analysis can only include filtered content; other comments may have been removed in the moderation process. The provided numbers therefore only indicate trends in the material. However, the material does not lend itself to quantitative analysis.

\section{Findings}

The following four themes emerged as most common and were thus used when coding the data for analysis:

- Negotiating for translations

- Discussion of translations

- Meta-discussion of the international SKAM fandom

- Valuing Norwegian as a precious resource.

The first theme identified was negotiating for translations. In the initial identification of themes, around 250 comments were identified as requests for translation, while around 90 comments were direct responses to such requests, translations themselves not included. These comments directly discuss the act of providing translations of posts on the website, both from the perspectives of those in need of translations and from the perspectives of those providing them, who are either willing or unwilling to do so.

Most common are translation requests from non-Norwegian speakers. There are often multiple requests for the translation of the same post, probably partly due to delays caused by NRK's moderation but presumably also because some posts had a very large number of comments where previous translations might get lost. Posts commonly engendered several hundred comments; at the time of writing this paper, the final clip of the season had more than 1,500 comments. Requests are generally of three types, namely requests that a Norwegian speaker provide a translation in the comments (around 190), requests for recommendations for where to find translations (less than 10), and requests that NRK provide translation (around 30). Some requests were too general to categorize, such as comments saying, "English, please," without any context.

Requests for a translation are often extremely polite, expressing gratitude in advance to anyone willing to translate, such as the request, "Any gentle soul to translate this?" Praising translators may be a way for non-Norwegian speakers without direct access to the SKAM content to ensure a positive relationship with those fans who have knowledge of Norwegian, and consequently, the power to provide access to the series, in order to obtain the necessary translations. Such requests appear to invoke the culture of gift-giving common to online media fandom (Hills 2002a, Jenkins, Ford, \& Green 2013) but also make visible the linguistic hierarchy of this fandom (Hills 2002a, 2002b, Jenkins \& Carpentier 2013), with power clearly located with multicompetent language users who can provide fans who do not speak Norwegian with access to the desired content. 
The polite wording and hedging underscore that the translation-requesting commentator relies on the multicompetent language user to understand the show and positions him-/herself as politely subservient.

However, there are also quite a few requests which could be perceived as less polite, for example, comments simply saying, "Translation, please." As we will see later, these are sometimes perceived by Norwegian fans as entitled, and may induce negative responses. These tensions may stem from different English proficiency levels and experience with different communities of practice or ELF situational contexts (e.g. Hülmbauer 2009). As discussed above, English competence in Scandinavia is generally high (Education First 2017), and as we will see below, not all Norwegian fans seem to consider that international fans may also be non-native speakers of English. They may therefore expect adherence to politeness norms by other international fans who may either lack familiarity with these norms or may be used to using English in a milieu in which inclusion of a terminal "please" is considered a sufficient signal of politeness, while it is not perceived as appropriate by others in this fandom. Thus, these may be rare examples where deviation from standard English (politeness) norms causes a communication breakdown.

The second type of request for translation asks for recommendations for where to watch SKAM with English subtitles, for example, "There's any way to watch it in English subtitles?" These appear to come mainly from new fans who are not yet aware that official translations do not exist. This shows how induction into fandom is often facilitated by more experienced fans and demonstrates the process of enculturation into fandom (Hellekson \& Busse 2006:13, see also Jenkins 1992/2013). Some ask specifically for unofficial channels such as YouTube or Tumblr, which may perhaps demonstrate their familiarity with the channels of distribution commonly used by online media fandoms, suggesting that they are not necessarily new fans but fans new to the SKAM fandom in particular.

The last type of request for translation consists of explicitly telling NRK that they should provide subtitles, for example, "Please add english subtitles." Again, these seem to come mostly from fans who have just discovered the series and are usually followed by other comments explaining why such subtitles do not exist. Some of these comments are quite temperamental, criticizing NRK's perceived financial motives for keeping the series "to themselves." This suspicion of NRK's motives demonstrates the anti-consumerist, prodemocratic impulse of media fandom more generally, suggesting that fans are suspicious of corporations' capitalistic motivations (Hills 2002a, Jenkins, Ford, \& Green 2013).

With the many requests for translations, it is not surprising that the second most common type of comment in our material is responses to translation requests. These of course include the translations themselves, of 
which there are often several for a single request. ${ }^{2}$ This is likely due to the lag in NRK's moderation and posting of comments rather than implying that fans intended to correct already provided translations, but it presumably also reflects that many fans are happy to provide and clarify translations, evincing the participatory and collaborative culture of online media fandoms (Jenkins 1992/2013). We discuss this in more detail below.

Explicit responses to requests for translation are twofold; most responses show that Norwegian fans are happy to help and to provide translations as free "gifts" (Hills 2002a, Jenkins, Ford, \& Green 2013), but some imply that non-Norwegian fans should find other ways to understand the series and not bother the Scandinavian fans with translation requests. These latter responses display the factional, rather than democratic, side of fandom (Hills 2002a) and also display some fans' resistance to online fan communities' impulse to provide free labor and gifts or an individualist resistance to communityfocused, collectivist ideologies.

Positive responses that fans are happy to translate might consist of the translation itself; there are around 400 translations in total, including translations of entire clips, summaries, and explanations of individual words. Translators sometimes use the field intended for names to add headings such as "Happy to help" or "Here you go," underscoring the translation as a gift (Hills 2002a, Jenkins, Ford, \& Green 2013). In some cases, Scandinavian-speaking fans explicitly post comments to say that they enjoy providing translations or that they are happy to share the series with the international fandom, showing their pride in their local language and culture (Hills 2002b, Morimoto 2018) and displaying their enjoyment of the transnational SKAM fandom, that is, as an online space that demonstrates patterns of exchange and provides affirmative social affiliation in spite of borders (Vertovec 2009). After a translation request where someone apologizes for being annoying, one response is, "Don't worry, most of us don't find it annoying that you want translations. We LOVE the fact that you love the show too!" This suggests that the fans providing translations experience transnational socialization as "encouraging" (Williams 2012:28).

Sometimes, positive comments are given in direct response to negative comments. When someone tells international fans to stop requesting translations, this is usually immediately countered by others defending the right of international fans to enjoy the show. One Norwegian fan, for example, says (s)he is ashamed of the lack of hospitality reflected in such responses, while another uses the field intended for a name in her translation to say, "Makes us proud! Almost every show we watch in Norway are in English, so im just glad to translate for you." These exchanges underscore several of the themes

2 It should be noted that English is not the only language into which there are translations. We did come across a handful of translations into other languages (French, German, Spanish) in our material. However, since these translations were very few and were not systematically searched for, we do not discuss them here. It remains clear that the preferred language of international communication in the SKAM fandom is English. 
discussed in the background section. Firstly, they show that while the SKAM fandom is largely encouraging, participatory, and polite, it nonetheless has its various factions (Hills 2002a), who hold different beliefs about the fandom's transnationality. For some fans, part of the enjoyment of the size and scope of the SKAM fandom appears to be that, counter to most popular culture watched in Norway, this show is not an English-language show; as such, these fans appear to enjoy its success precisely because it subverts the prevalence of English in popular culture (Hills 2002b, Pennycook 2003, Williams 2012). They also enjoy the international attention received by the show, which makes them "proud" of their language and culture, reflecting how fans' English use can, perhaps counterintuitively, bolster pride in local languages and cultures (Pennycook 2003). However, these clashes between fans also demonstrate the more protectionist and nationalistic impulses that transnationalism and translation can inspire (Graedler 2014, Pennycook 2003, Williams 2012, Woolard \& Scheiffelin 1994).

Less positive responses to translation requests often politely ask international fans to look for translations that have already been provided previously in the comments to the same post, and quite often a smile or heart emoji is used in such responses, indicating that they are not meant to be negative, such as, "scroll up <3." Sometimes, reference is made to external channels distributing the show with subtitles, such as YouTube. However, other comments express frustration over repeated translation requests, in particular if those requests are not politely worded. One comment refers to these requests as "whining" and another complains that the constant requests for translation "clog up" the comments sections. One commentator even wants to exclude all non-Norwegian speakers from the website: "honestly. Non Norwegian folks dont belong here. please comment on the illegal ones on yt." Such comments can be seen as a form of linguistic and cultural protectionism. This sentiment, however, does not seem to extend to other Scandinavians experiencing comprehension problems, as questions from Danish fans, for example, do not seem to receive such responses; it seems that it is English which is perceived as the threat in this context, perhaps reflecting the wider cultural trope in Norway of discussing English as a threat to Norwegian (Graedler 2014). Again, any negative comment of this kind is usually followed by a number of counteractive comments, such as, "Honestly you should be happy that Skam is getting lots of love and support from all around the world, no need to hate, plus it doesn't affect you in any way!" Thus, it appears that while some fans' linguistic ideologies are protectionist and nationalistic (Pennycook 2003, Williams 2012, Woolard \& Scheiffelin 1994), others view English as a way in which to share local languages and cultural products, and thus, to feel pride at the attention (Pennycook 2003, Williams 2012).

Comments providing discussion of translations can be divided into selfevaluation of one's own translation and evaluations and discussion of others' translations. 
Self-evaluation is not extremely frequent. It usually expresses self-doubt in the translation. We identified around 60 such instances, where about 20 were fairly direct comments that the translation provided was bad, such as, "Sorry for the norwenglish translate, but you will get the essence," while the rest were more subtle apologias. Sometimes this simply entailed using the field intended for providing a name for a comment, such as "I tried," or even more subtly, "Translation-ish" or "English-ish." However, it is not very common to see translators apologize for their English. Commentators instead express doubt in translation choices or point to a lack of direct cognates in the target language: "Sounds a bit strange, sorry. Some Norwegian slang is hard to translate!" They also apologize for the haste of translation - as in, "typing to fast, sorry" - or for possibly having forgotten to translate everything. Some emphasize that several people spoke simultaneously in a clip, making it hard to correctly translate, such as when a translator ends his post, "given the many voice overlaps in this clip, errors are likely." They express hope that their translation helped. In some cases, Danish speakers also apologize for having possibly misunderstood the Norwegian. In one particularly interesting comment, the translator apologizes for his/her translation by saying, "don't hate on my translations i didn't know how to language." Nonetheless, it is clear that the volunteer translators' focus is on comprehensibility and an accurate rendering of what takes place in the original clip or text rather than on writing prescriptively correct English. Thus, while some fans may feel self-conscious about their own English compared to more proficient users, their comments still seemingly reflect a view of ELF rather than a native speaker ideal (e.g. Hülmbauer 2009, House 2013, Švelch 2013), and that translators see themselves as multicompetent language users (Cook 1991, 1992), where it is not necessarily the L2 that causes errors.

Evaluations of translations by others are also relatively infrequent; expressions of gratitude are much more common than comments on the quality of the translation itself. Around 70 comments could be said to be such evaluations, and when such comments appear, they are often responses to expressions of self-doubt by the translator. These responses are overwhelmingly positive and, again, generally address the quality of the translation in terms of choices and intelligibility rather language correctness or native-likeness. For example, when a translator ends her entry with "From a girl that isent that good in English," the response is, "Thank you. Your english is ok. Dont worry." In the few cases that comments are in fact negative, they generally do not focus on non-native forms or language errors in the English provided but rather on whether the language is coherent and on whether the Norwegian, often teenage slang, has been understood correctly. An example is the comment, "what an awful translation. makes little sense," or, in discussing whether "freaking lovely" is really the best translation of the Norwegian term jovlig deilig, "More like 'you're so $\mathrm{f}^{* * *}$ ing hot Isak' at the end there. Or ' $\mathrm{f}^{* * *}$ ing delicious' or something." Thus, although we did not analyze the translations themselves and cannot make strong claims about preferred approaches to translation (e.g. 
literal versus idiomatic translation), a few comments may entail disagreement over which approach is most appropriate. Some comments simply entail discussion of the best explanation of a Norwegian word for a non-Norwegian audience; in fact, 36 comments deal just with the correct explanation of the Norwegian word $d$ ust.

A few translations do elicit overwhelmingly negative responses, but these have clearly been translated using Google and are not only incorrect but also nonsensical; these few posts count for a significant proportion of the overall number of evaluations. One example is when Isak's roommate Noora comments that she has a gutt 'boy' (meaning boyfriend) and this is translated as her saying she has a "kid," which is obviously wrong in the context. Another translation which has received many correcting comments accidentally translates Ibiza as "a pizza," resulting in a muddled, nonsensical metaphor. Again, the error is clearly in the comprehension of the Norwegian dialogue - in this case, probably simply mishearing - not in the translator's English. There are around 15 comments correcting a translator's English, but these seem to be by other Norwegians and, again, almost exclusively deal with content rather than the language itself, for example arguing that "grilled cheese" is a better translation for ostesmørbrød than "toast." This suggests that the community takes a collaborative approach to translation and that the SKAM fandom considers itself to be a collaborative, participative community (Jenkins 1992/2013) - focus here is on working together to provide the best translation possible for a wider audience. However, lack of critique may also indicate a lack of desire to criticize those seen as "saviors," that is, the translators whose gifts make possible non-Norwegians' participation in the fandom in the first place (Švelch 2013). Aside from a few instances where someone was called out for using Google Translate, we identified only 5 comments that complained that the translation was poor, and only one relating this directly to the translator's English - and this comment was in Norwegian.

A number of comments provide a meta-discussion of the international $S K A M$ fandom. This theme appears in requests for translation, in the responses to such requests, and in the translations themselves, as requests are often claimed to be on behalf of all non-Norwegian speakers and responses and translations tend to be explicitly addressed to international fans. However, there is also discussion of aspects of the international fandom outside of these exchanges. Such discussions typically entail someone's expressing enthusiasm over the international spread of the show and asking where other fans are from: "Curious to know where all you non-Norwegian skam fans come from. So cool you have discovered this." Such comments often lead other fans to name their country and add information about how they learned about the show. This interest in the fandom and desire to create social ties based on popular cultural affinity is a common aspect of online media fandoms (e.g. Harrington \& Bielby 2007, Hellekson \& Busse 2006, Hills 2002a, Jenkins 1992/2013, Jensen 2003, Kusteritz 2015). 
This theme has elicited a number of comments theorizing what "English speaker" means in this community. Occasionally, fans are mocked for the English used in an independent comment which is not a translation. In every case we have identified where this occurs, however, the critical comment claims that the language errors reveal the author as a Norwegian pretending to be an international fan, and the comment's criticism is of the other fan's supposed disingenuousness. In three cases, subsequent commentators argue that non-Norwegians who are not native English speakers would also use English to comment. For example, where the critical comment claims, "Only Norwegians write English like that," the original commentator replies that (s)he is German. Thus, the criticism in these comments is not aimed at the quality of English per se but rather at the perceived dishonesty of Norwegians pretending to foreigners. This may in turn reflect concern that Norwegians may prefer to use English over Norwegian due to its perceived higher status, and thus that Norwegian may be under threat (cf. Mæhlum 2008, Graedler 2014). Responses suggesting that English is the natural language to use in transcultural exchanges online reveal commentators' subscription to the belief that English can be used as an international language of communication regardless of interlocuters' mother tongues (e.g. Crystal 2012).

Another example of the ambiguity found in the comments about who the "English speakers" are is found in discussion of the song accompanying the clip "O helga natt." This song, generally known in Norway by the same Swedish title as the clip itself, is in fact the song originally entitled "Minuit, chrétiens" in French. When one fan asks, in English, what the song is, the response from one Norwegian is that "you have it too," explaining that it is "O Holy Night." The Norwegian fan thus clearly assumes that (s)he is interacting with a native speaker of English, although nothing in the original request for information indicates that this is so.

Comments also mention other internationally available platforms for watching SKAM in English, such as YouTube, Tumblr, or Twitter. These comments are sometimes responses to translation requests, but there are also cases where fans apologize for requesting a translation by saying that a YouTube channel used to watch the show has been taken down or explaining that they discovered the show through Tumblr but cannot find a translation. It is clear that for many, the comments section on skam.p3.no is just one of many platforms where they come together as a fandom to follow and discuss the series.

A number of comments relate to the theme valuing Norwegian as a precious resource. Such comments sometimes express regret for not speaking Norwegian; for example, one fan describes him-/herself as unfortunate not to speak Norwegian. Many express frustration in their own lack of Norwegian, especially late at night, when there is a delay in fan-produced translations, for example, "Help help help there are no translations up yet this is so painful," 
and, "When you can't understand a word bc the translator is asleep." These comments may also praise the Norwegian language itself, as in the comment, "until I understand this beautiful language, may someone help me and translate it, pls?" Lack of Norwegian comprehension is clearly shown as a disadvantage in a sequence where someone posts the comment, "I DONT UNDERSTAND BUT I ALREADY LIKE IT," eliciting the response, "You should wait until translation hits you before commenting.. not likeable," indicating that the clip did not end well. These comments clearly underscore the ways in which subcultural capital (Schules 2014) accrues around Norwegian speakers and, particularly, multicompetent translators within the fandom, and they demonstrate how much power and importance these figures have within the fandom. As such, multicompetent Norwegian speakers can be considered to hold a position at the top of a subcultural hierarchy in the SKAM fandom (e.g. Hills 2002a).

The value of Norwegian competence in the fandom can also be seen in the frequent expressions of gratitude to fans who provide translations. These are abundant in connection with further requests for translation, that is, in contexts where they can be seen as strategies to obtain not only a single translation but also future translations. However, there are also many independent comments discussing how important the volunteer translators are and how grateful the international community is to translators. One fan responds to a question about how non-Norwegians understand the show, "We rely on the lovely bilingual Norwegian people on internetland to help us out with the dialogue." Such comments further underscore the power of the multicompetent Norwegian user, as they show how non-Norwegianspeaking fans openly demonstrate subservience and gratitude in order to elicit goodwill and future "gifted" translations (Hills 2002a, Schules 2014). Many such comments describe translating tools as inadequate. In one sequence, an international fan has worried unnecessarily about Even's health because of a poor Google translation and expresses extreme gratitude when Norwegian fans explain that (s)he has misunderstood.

This theme in the comments illustrates how the international fandom depends on those with competence in Norwegian and can thus be seen as subverting the narrative of "linguistic imperialism" (Phillipson 2009) in awarding prestige to multicompetence and non-English proficiency. This is further emphasized by the translators themselves, when they explain features of the Norwegian language or Norwegian culture that they find difficult to translate directly or provide details in addition to a translation to ensure that non-Norwegian viewers will understand. Such meta-comments in translations may, for example, explain the names or locations of streets or landmarks in Oslo, translate and describe acronyms for Norwegian institutions, or address linguistic issues such as idioms or puns that cannot be directly translated. For example, when Isak's roommate Eskild uses a Norwegian idiom which implies hospitality incorrectly and is subsequently corrected by roommate Linn, a 
translator says, "OKay, the whole heartroom-thing is an norwegian saying I have no Idea how to translate correctly."

Yet other comments express pride in understanding Norwegian. Often, such comments are linked to inter-Scandinavian comprehension, for example, Swedes and Danes explaining that they have understood a clip without subtitles. There are also examples of Icelandic and Finnish fans commenting that they understand a lot because they have learned Danish and Swedish, respectively, in school; for example, one Icelandic fan writes, "Finally I understand why I had to learn Danish for 6 years." Finally, there are examples of non-Scandinavians discussing their comprehension of Norwegian; some explain that they have actually learned it and are happy to be able to follow the show, while others describe increasing comprehension of the language through watching the series, such as a German fan commenting, "I basically watched so much Skam with undertitles that I can guess some things." Again, we see how the series carves out a space for valuing non-English language competence - knowledge of Norwegian is not only valued in this online space as giving one the freedom of direct access to the show's content but also allows one to accrue subcultural capital and demonstrate one's place in the SKAM fan hierarchy or one's dedication to the show, the fandom, or the culture that produced the show (Hills 2002a, Schules 2014).

Other comments address inter-Scandinavian comprehension problems. For example, Danish speakers may complain that they do not understand some of the spoken Norwegian or ask for clarification of particular words; discussion and explanation of these words sometimes ends up being in English. In one place, for example, a Danish fan asks about two Norwegian slang terms, and one reply starts, "I'll do this in English for the sake of simplicity," and then goes on to explain the terms in English. Thus, although comprehension of a Scandinavian language is often highlighted as an asset in the comments, at times, it is clear that Norwegian competence is in fact needed to independently comprehend the series.

\section{Discussion and Conclusion}

Our analysis identified four main themes in our data, namely "negotiating for translations," "discussion of translations," "meta-discussions of the international fandom," and "valuing Norwegian as a precious resource." Less prevalent themes have not been discussed.

Exchanges coded "negotiating for translations" largely celebrated the international fandom and demonstrated fandoms' gift-giving cultures (Hills 2002a, Jenkins, Ford, \& Green 2013). However, although the general sentiment certainly seems to be genial, we also saw evidence of attempts at exclusion, where comprehension of Norwegian was suggested to be a central criterion for inclusion in the fandom. This demonstrates the tensions and contradictions between fans' pride in and desire to share local languages and cultures with wider transcultural audiences as opposed to their protectionism 
of what is seen to be "theirs" (Chin \& Morimoto 2013, Hills 2002b, Pennycook 2003, Williams 2012) and might be linked to underlying language ideologies (Woolard \& Scheiffelin 1994). Although general apologies for using English were excluded from the data set, these could also be considered to demonstrate the tensions between effective transcultural communication (e.g. Crystal 2012, Hülmbauer 2009, House 2013) and local language protectionism (e.g. Graedler 2014, Woolard \& Scheiffelin 1994), or between the national and transnational (e.g. Chin \& Morimoto 2013, Hills 2002b, Morimoto 2018, Williams 2012), Norwegian fans feel regarding their choice of language.

This study suggests that translations can be simultaneously shared for the purposes of understanding as well as to foster a wider community and mark affiliation with a global youth culture. The multicompetent fan develops a community identity within the fandom through the use of English; at the same time as his/her local context inflects the fan's interaction with both the local and the transnational community (Hills 2002b, Jensen 2003). Multicompetence, particularly one including a knowledge of Norwegian, allows the SKAM fan to accrue power and subcultural capital within this online media fandom (Hills 2002a, Schules 2014). It is possible that multicompetent fans with knowledge of languages other than Norwegian and English also accrue power within specific SKAM-related fan communities and websites. Further research on language use in other contexts within this fandom would be welcome.

In comments discussing translations, we saw that neither translators nor other fans usually commented on the linguistic quality of the translation or on whether it was well-written in English. This is in line with previous research (Diaz-Cintas \& Muñoz Sànchez 2006, Švelch 2013). A few translators apologized for their English, but commonly, insecurities about one's own translation dealt with whether the translator had heard correctly or whether there were more accurate word choices which could improve the translation. Comments on the translations of others generally focused on content and clarity, and most were positive, with harsh criticisms given only to non-sensical translations provided by digital translation tools. In the few cases of criticism of the language of the translation, focus was on lexical choices and meaning, not on grammatical correctness. Such criticism seemed mostly to come from other Norwegians. Overall, the Norwegian fan community appeared more collaborative and participative (Jenkins 1992/2013) than competitive and factional (Hills 2002a), with a shared desire to provide accurate and cohesive English translations.

Importantly, praise of translations was far more common than criticism, which is again in line with earlier research (Švelch 2013). Power does not seem to be afforded to native speakers of English or those with native-like English competence. Rather, power is afforded to those with enough Norwegian proficiency to give others access to the series. This supports earlier assertions that power in international fandom relies less on linguistic accuracy than multicompetence (Schules 2014). It also supports the assertion that there is 
a tension in transnational fandoms between the democratic impetus driving translation-as-gift and the power and subcultural capital that translators accrue (Hills 2002a, Jenkins \& Carpentier 2013, Schules 2014).

This power is also evident in discussions of the international fandom, where the transnational community of SKAM fans is celebrated through discussion of how they access the content and how important the volunteer translators are, underscoring how complex linguistic repertoires are valued (Woolard \& Schieffelin 1994). There is some negative sentiment toward the use of English by those Norwegians who believe that English comments may be written by fellow Norwegians. This may demonstrate fans' desire that other fans be honest and a dislike of perceived disingenuousness but also seems to be driven by a misunderstanding of the possible motives for using English, such as communication with a global rather than local fan community; it may be linked to ideas that some Norwegians choose to use English simply for reasons of fashion and prestige (Johansson \& Graedler 2002, Preisler 1999, Språkrådet 1990) or to the belief that English use undermines the Norwegian language (Graedler 2014). This may be considered to further highlight cultural and linguistic protectionism (Chin \& Morimoto 2013, Pennycook 2003) or to emphasize the perceived value of a specific "subcultural identity ... and peer group solidarity" (Preisler 1999:246-47). While Preisler (1999:246) has argued that in Scandinavia, English is often used by youth to "symbolize subcultural identity," it appears that using it can also signal the "wrong" impulses or affiliations for some.

It is important to note that Norwegian and English are used as identitybuilding or -demonstrating tools by SKAM fans in various ways. While most Norwegians in our data use their Norwegian and English competence as a way to share their culture, and thus to accrue subcultural capital and feel pride within the transnational online fandom (e.g. Crystal 2012, Hills 2002a, Hülmbauer 2009, House 2013, Schules 2014), there are also examples where fans reject this sharing impulse and instead demonstrate a more protectionist attitude that may reflect a traditional resistance to loan words and foreign linguistic influence (Graedler 1998, Pennycook 2003). Foreign fans, too, may use a burgeoning Norwegian competence to gain subcultural capital within the fandom. As such, we can consider this transnational online fandom to contradictorily be a space which for some fans "exceed[s] hegemonic state definitions of the "national" (Morimoto 2018:282) yet nonetheless, for a minority group of fans, encourages protectionism (Pennycook 2003, Williams 2012, Woolard \& Schieffelin 1994). This demonstrates that "fandom and national identity ... have a more complex relationship, one that does not simply locate fan cultures 'in' a given national context [or] 'against' other national contexts" (Hills 2002b:2). It instead suggests that local, national, and global contexts, including individual politics and language ideologies, inflect the "different pathways to identity formation" (Jensen 2003:195) that participation in a transnational online fandom opens up. 
Finally, comments illustrating the role of Norwegian as a precious resource highlight some of the central tensions of a transnational fandom centered on a non-Anglo phenomenon (Chin \& Morimoto 2013, Pennycook 2003). While virtually all discussion within the international fan community is in English, the language projected as being of value is that of the series itself: Norwegian. Thus, the series and its fandom subverts the power of English and its "linguistic imperialism" (Phillipson 2009) by affording power to those who can access it in its original Norwegian form.

\section{References}

Andersen, Tor Rye; and Sara Tanderup Linkis (2019). As we speak: Concurrent narration and participation in the serial narratives '@I_Bombadil' and Skam. Narrative, 27, 83-106. Online: https://muse.jhu.edu/article/712872.

Bjørkedal,IdunnHåvik(2018). Whathappened to "ass"? Astudyofthefansubbingof Norwegian slang into English in the TV-show Skam and its effects on characterization (Unpublished master's thesis). Norwegian University of Science and Technology, Trondheim, Norway. Online: https://brage.bibsys.no/xmlui/handle/11250/2574560?show=full.

Black, Rebecca W. (2005). Access and affiliation: The literacy and composition practices of English-language learners in an online fanfiction community. Journal of Adolescent and Adult Literacy, 49, 118-28. Online: https://pdfs.semanticscholar. org/627f/9be6258a692fa4f9bd5c4103839287e6c360.pdf.

Black, Rebecca W. (2008). Adolescents and online fan fiction. New York: Peter Lang.

Black, Rebecca W. (2009). English-Language learners, fan communities, and 21st-century skills. Journal of Adolescent \& Adult Literacy, 52, 688-97. Online: https://www.jstor.org/ stable/27654331.

Bricker, Tierney (2017). TV's top couple 2017 has a winner and they're thanking "the coolest fanbase on earth." E!News, March 8 2017. Online: https://www.eonline.com/news/834591/ tv-s-top-couple-2017-has-a-winner-and-they-re-thanking-the-coolest-fanbase-on-earth.

Chin, Bertha; and Lori Hitchcock Morimoto (2013). Towards a theory of transcultural fandom. Participations: Journal of Audience and Reception Studies, 10, 92-108. Online: http:// www.participations.org/Volume\%2010/Issue\%201/7\%20Chin\%20\&\%20Morimoto\%20 10.1.pdf.

Chin, Bertha; Aswin Punathambekar; and Sangita Shresthova (2018). Advancing transcultural fandom: A conversation. The Routledge companion to media fandom, ed. by Melissa A. Click and Suzanne Scott, 298-306. London: Routledge.

Click, Melissa A.; Jonathan Gray; Jason Mittell; and Suzanne Scott (2018). Futures of fan studies: A conversation. The Routledge companion to media fandom, ed. by Melissa A. Click and Suzanne Scott, 437-50. London: Routledge.

Cook, Vivian (1991). The poverty-of-the-stimulus argument and multicompetence. Second Language Research, 7, 103-17. Online: https://journals.sagepub.com/doi/ abs/10.1177/026765839100700203.

Cook, Vivian (1992). Evidence for multicompetence. Language Learning, 42, 557-91. Online: https://onlinelibrary.wiley.com/doi/abs/10.1111/j.1467-1770.1992.tb01044.x.

Coppa, Francesca (2006). A brief history of media fandom. Fan fiction and fan communities in the age of the internet, ed. Karen Hellekson and Kristina Busse, 41-60. Jefferson: McFarland. 
Jennifer Duggan \& Anne Dahl

Scandinavian Studies in Language, 10(2), 2019 (6-29)

Crystal, David (2008). Two thousand million? English Today: The International Review of the English Language, 24, 3-6. Online: https:/www.cambridge.org/core/journals/englishtoday/article/two-thousand-million/68BFD87E5C867F7C3C47FD0749C7D417.

Crystal, David (2012). English as a global language. Cambridge: Cambridge University Press.

Deppey, Dirk (2005). Scanlation nation: Amateur manga translators tell their stories. The Comics Journal, 269, n.p. Online: https://www.insidescanlation.com/etc/tcj/n_scan.

Díaz Cintas, Jorge; and Pablo Muñoz Sánchez (2006). Fansubs: Audiovisual translation in an amateur environment. The Journal of Specialised Translation, 6, 37-52. Online: http:// www.jostrans.org/issue06/art_diaz_munoz.pdf.

Education First (2017). English proficiency index. Online: https://www.ef.no/epi/.

Fabretti, Matteo (2017). Manga scanlation for an international readership: The role of English as a lingua franca. The Translator, 23, 456-73. Online: https:/www.tandfonline.com/doi/ full/10.1080/13556509.2017.1385938.

Geertz, Clifford (1973). The interpretation of cultures. New York: Basic Books.

Graedler, Anne-Line (1998). Morphological, semantic and functional aspects of English lexical borrowings in Norwegian. Oslo: Universitetsforlaget.

Graedler, Anne-Line (2014). Attitudes towards English in Norway: A corpus-based study of attitudinal expressions in newspaper discourse. Multilingua, 33, 291-312. Online: https:// www.degruyter.com/view/j/mult.2014.33.issue-3-4/multi-2014-0014/multi-2014-0014. $\mathrm{xml}$.

Gray, Jonathan; Cornel Sandvoss; and C. Lee Harrington, eds. (2007). Fandom: Identities and communities in a mediated world. New York: New York University Press.

Harding, Sandra (1995). "Strong objectivity": A response to the new objectivity question. Synthese, 104, 331-49. Online: https://www.jstor.org/stable/20117437.

Haraway, Donna (2006). A cyborg manifesto: Science, technology, and socialist-feminism in the late twentieth century. The international handbook of virtual learning environments, ed. In Joel Weiss; Jason Nolan; Jeremy Hunsinger; and Peter Trifonas, 117-58. Dordrecht: Springer. (Original work published 1985)

Harrington, C. Lee; and Denise D. Bielby (2007). Global fandom/global fan studies. Fandom: Identities and communities in a mediated world, ed. Jonathan Gray; Cornel Sandvoss; and C. Lee Harrington, 179-97. New York: New York University Press.

Hellekson, Karen; and Kristina Busse (2006). Introduction. Fan fiction and fan communities in the age of the internet, ed. Karen Hellekson and Kristina Busse, 5-32. Jefferson: McFarland.

Hersdal, Helene Foldvik (2018). "Er dritkul kun med et t? mit liv er en løgn”: En sosiolingvistisk studie av metadiskurser om språk $i$ en SKAM-nettgruppe (Unpublished master's thesis). Norwegian University of Science and Technology, Trondheim, Norway. Online: https://brage.bibsys.no/xmlui/handle/11250/2563620.

Hills, Matt. (2002a). Fan cultures. London: Routledge.

Hills, Matt. (2002b). Transnational otaku: Japanese representations of fandom and representations of Japan in anime/manga fan cultures. Online: https://cmsw.mit.edu/mit2/ Abstracts/MattHillspaper.pdf.

House, Juliane (2013). English as a lingua franca and translation. The Interpreter and Translator Trainer, 7, 279-98. Online: https://www.tandfonline.com/doi/abs/10.1080/13 556509.2013 .10798855$.

Hülmbauer, Cornelia (2009). "We don't take the right way. We just take the way that we think you will understand" - The shifting relationship between correctness and effectiveness in ELF. English as a lingua franca: Studies and findings, ed. Anne Mauranen and Elina Ranta, 323-47. Newcastle: Cambridge Scholars Publishing. 
Jenkins, Henry (2013). Textual poachers: Television fans and participatory culture. London: Routledge. (Original work published 1992)

Jenkins, Henry; and Nico Carpentier (2013). Theorizing participatory intensities: A conversation about participation and politics. Convergence: The International Journal of Research into New Media Technologies, 19, 265-86. Online: https://journals.sagepub. $\mathrm{com} / \mathrm{doi} / \mathrm{abs} / 10.1177 / 1354856513482090$.

Jenkins, Henry; and Suzanne Scott (2013). Textual poachers twenty years later: A conversation between Henry Jenkins and Suzanne Scott. Textual poachers, by Henry Jenkins, vii-1. London: Routledge.

Jenkins, Henry; Sam Ford; and Joshua Green (2013). Spreadable media. New York: New York University Press.

Jensen, Lene Arnett (2003). Coming of age in a multicultural world: Globalization and adolescent cultural identity formation. Applied Development Science, 7, 189-96. Online: https://www.tandfonline.com/doi/abs/10.1207/S1532480XADS0703_10.

Johansson, Stig; and Anne-Line Graedler (2002). Rocka, hipt og snacksy: om engelsk i norsk språk og samfunn. Kristiansand: Høyskoleforlaget.

Kachru, Braj (1991). Liberation linguistics and the Quirk Concern. English Today, 7(1), 3-13. Online: https://www.cambridge.org/core/journals/english-today/article/liberationlinguistics-and-the-quirk-concern/461B1D60985AE073B77643BC1DF75770

Kusteritz, Anne (2015). Transnationalism, localization, and translation in European fandom: Fan studies as global media and audience studies. Transformative Works and Cultures, 19, n.p. Online: https://journal.transformativeworks.org/index.php/twc/article/view/682/517.

Lam, Wan Shun Eva (2006). Re-envisioning language, literacy, and the immigrant subject in new mediascapes. Pedagogies: An International Journal, 1, 171-95. Online: https://www. tandfonline.com/doi/abs/10.1207/s15544818ped0103_2.

Leavitt, Alex (2010). Inside scanlation. Transformative Works and Cultures, 5, n.p. Online: https://journal.transformativeworks.org/index.php/twc/article/view/215/172.

Lindgren, Simon (2013). Sub*culture: Exploring the dynamics of a networked public. Transformative Works and Cultures, 14, n.p. Online: https://journal.transformativeworks. org/index.php/twc/article/view/447/359.

Massidda, Serenella (2015). Audiovisual translation in the digital age: The Italian fansubbing phenomenon. Basingstoke: Palgrave Macmillan.

Morimoto, Lori Hitchcock (2018). Transnational media fan studies. The Routledge companion to media fandom, ed. by Melissa A. Click and Suzanne Scott, 280-88. London: Routledge.

Mæhlum, Brit (2008). Skal vi la norsk språk være en ulempe - i Norge? Språknytt, 36, 21-24. Online: https://www.sprakradet.no/Vi-og-vart/Publikasjoner/Spraaknytt/Arkivet/ Spraknytt-2008/Spraknytt-12008/Skal-vi-la-norsk-vare-en-ulempe-i-Norge/.

O'Hagan, Minako (2009). Evolution of user-generated translation: Fansubs, translation hacking and crowdsourcing. The Journal of Internationalization and Localization, 1, 94 121. Online: https://benjamins.com/catalog/jial.1.04hag/fulltext.

O'Hagan, Minako (2011). Community translation: Translation as a social activity and its possible consequences in the advent of Web 2.0 and beyond. Linguistica Antverpiensia New Series: Themes in Translation Studies, 10, n.p. Online: https://lans-tts.uantwerpen.be/ index.php/LANS-TTS/article/view/275.

Pennycook, Alastair (2003). Global Englishes, Rip Slyme, and performativity. Journal of Sociolinguistics, 7, 513-33. Online: https://onlinelibrary.wiley.com/doi/abs/10.1111/ j.1467-9841.2003.00240.x.

Phillipson, Robert (2009). Linguistic imperialism continued. New York: Routledge.

Preisler, Bent (1999). Functions and forms of English in a European EFL country. Standard English: The widening debate, ed. Tony Bex and Richard J. Watts, 239-68. London: Routledge. 
Quirk, Randolph (1990). Language varieties and standard language. English Today, 6(1), 3-10. Online: https://www.cambridge.org/core/journals/english-today/article/languagevarieties-and-standard-language/CDC64015158BBB97EDAD1E882D7951C2

Quist, Pia; and Astrid Ravn Skovse (2017). Sprog i og uden om SKAM: Autenticitetselement, fællesskabsmarkør og vare. Nordisk Tidsskrift for Informationsvidenskab og Kulturformidling, 6, 43-53. Online: https://tidsskrift.dk/ntik/article/view/99070.

Schules, Douglas (2014). How to do things with fan subs: Media engagement as subcultural capital in anime fan subbing. Transformative Works and Cultures, 17, n.p. Online: https:// journal.transformativeworks.org/index.php/twc/article/view/512/461.

Seidlhofer, Barbara (2005). English as a lingua franca. ELT Journal, 59, 339-41. Online: https://academic.oup.com/eltj/article/59/4/339/371345.

Simons, Gray F.; and Charles D. Fennig, eds. (2018). Ethnologue: Languages of the world, twenty-first edition. Dallas: SIL International.

Spolodorio, Samira (2017). Fansubbing in Brazil: Fan translation and collaborative production in light of participatory culture. Journal of Translation Studies, 18, 61-89. Online: https:// www.researchgate.net/profile/Samira_Spolidorio/publication/321024669_Fansubbing in_Brazil_Fan_translation_and_collaborative_production_in_light_of_Participatory_ Culture/links/5a7bd5a9458515c95de4c0eb/Fansubbing-in-Brazil-Fan-translation-andcollaborative-production-in-light-of-Participatory-Culture.pdf.

Språkrådet (1990). Ja til norsk! Informasjons- og debatthefte om engelsk i norsk. Oslo: Norsk språkråd.

Språkrådet (2017). Språkstatus 2017: Språkpolitisk tilstandsrapport frå Språkrådet. Online: http://www.sprakradet.no/globalassets/vi-og-vart/publikasjoner/sprakstatus/ sprakstatus-2017.pdf.

Švelch, Jaroslav (2013). The delicate art of criticizing a saviour: 'Silent gratitude' and the limits of participation in the evaluation of fan translation. Convergence: The International Journal of Research into New Media Technologies, 19, 303-10. Online: https://journals. sagepub.com/doi/10.1177/1354856513486531.

TNS Kantar (2017). Mediebarn 2017. Online: http://www.sprakradet.no/globalassets/vi-ogvart/rapporterog-undersokelser/mediebarn-2017-rapport.pdf.

Vertovec, Steven (2009). Transnationalism. London: Routledge.

Widdowson, H. G. (1994). The ownership of English. TESOL Quarterly, 28, 377-89. Online: https://www.jstor.org/stable/3587438.

Williams, Bronwyn T. (2012). The world on your screen: New media, remix, and the politics of cross-cultural contact. New media literacies and participatory popular cultures across borders, ed. Bronwyn T. Williams and Amy A. Zenger, 17-32. London: Routledge.

Woolard, Kathryn A.; and Bambi B. Schieffelin (1994). Language ideology. Annual Review of Anthropololgy, 23, 55-82. Online: https://www.annualreviews.org/doi/abs/10.1146/ annurev.an.23.100194.000415. 